\section{Thanks, and Goodbye to All That}

Correspondence concerning this column should be addressed to Barry Trott, RUSQ Editor, 7770 Croaker Rd., Williamsburg, VA, 23188; e-mail: btrott@wrl.org. n her final RUSQ column before turning over responsibility for the journal to me, editor Diane Zabel noted, "I wish Barry the best of luck and know that he too will find the editorship a gratifying experience." I have to say that both of those things came to be, and I am ever grateful to Diane and the RUSA Board for giving me a position that provided both challenges and satisfactions beyond what I had imagined.

As far as the luck goes, I have had the great fortune over the past six years to work with an excellent board. Jenny Bossaller, Heidi Jacobs, Kate Kosturski, Scott Seaman, Carol Singer, Nicolette Sosulski, Laurie Tarulli, Dave Tyckoson, Chiang Wang, and Neal Wyatt have helped shape my thinking about scholarly publishing and reference service and in doing so have helped to move RUSQ forward, building on the strong foundation that was laid by earlier boards and editors. In particular, the board's active advocacy for moving the journal to fully open access was essential to reaching that goal with the current volume. Board members also do most of the peer-reviewing of incoming submissions, and their thoughtful comments and attention to detail not only make the life of the editor much easier but also make the authors' work stronger.

RUSQ's columns often open up new directions in librarianship. I am lucky, and grateful, to have worked with a remarkable crew of column editors over the years. Marianne Ryan and Laurie Tarulli, editors of the Management and Readers' Advisory columns, respectively, have been with me for my entire run of the journal. Their thoughtful contributions and shepherding of authors is greatly appreciated. Eric Phetteplace (Accidental Technologist), Lisa O'Conner (Information Literacy), Kelly Myer Polacek (Alert Collector), and Karen Antell and Molly Strothman (Taking Issues) brought thoughtful new voices to the journal in my early editorship. Later, Aimee Graham took on the Alert Collector, and Kelly shifted to Information Literacy, and both continued the good work of their predecessors. Nicole Eva and Erin Shea joined the team in 2014 with a new column about library marketing (Amplify Your Impact) that has opened my eyes, and I hope those of all our readers, to the need to engage with our users more effectively. In 2016, we added three new column editors for existing columns as Esther Grassian and Sarah LeMire took on Information Literacy, and Mark Shores picked up the Alert Collector. We also added a new column focusing on our core, reference service, A Reference for That, co-edited by board members Dave Tyckoson and Nicolette Sosulski. Karen Antell, Tammy Voelker, and Anita Slack have brought readers hundreds of reviews of professional and reference 
materials to assist our work in selection and in professional development. All of these column editors have selected topics, guided authors, corrected grammar, checked references, and gotten manuscripts to me on time (almost always). It has been a great pleasure to work with them, and I have learned a great deal about the profession from reading their columns in proof.

Editing a journal is about more than soliciting authors and reviewing manuscripts. There are myriad details that go into publishing. Tim Clifford at ALA Production Services has been a patient and careful guide for me over the past six years as we prepared the journal for publication. His knowledge of grammar and the Chicago Manual of Style are unimpeachable, and he was always available to catch errors, provide style suggestions, and gently keep a new editor on track in the world of scholarly publishing.

When there is a manuscript to review, if it involves some specialization or if a RUSQ Board member is not available, I have been able to draw on the talents of over two dozen occasional reviewers. These academic, public, and special librarians were all willing to take time from their busy professional lives to give cogent and helpful suggestions about submissions to the journal. Without their contributions, editing RUSQ would have been not only a harder job but a less rich one as well.

RUSQ and I have also had the privilege and good fortune to be supported by a variety of people in the RUSA office. Executive Directors Susan Hornung and Jessica Hughes helped to navigate the RUSA budget and other ALA requirements. Leighann Wood, Liz Markel, Andrea Hill, Melissa Tracy, and Jennifer Cross have all helped out over the years with marketing the journal and making it more accessible. I appreciate their commitment to our readers.

While I leave the editorship of RUSQ with regrets, I am delighted to announce that the new editor of the journal will be Kathleen Kern. Kathleen is currently director of the Miller Learning Center at the University of Georgia Libraries. She has published widely, including a book, multiple peer-reviewed articles, book chapters, and other articles, and has worked as an adjunct instructor for the library schools at both the University of Illinois at Urbana-Champaign and Rutgers University. Kathleen previously served as an RUSQ column editor (Accidental Technologist) and a member of the RUSQ Board, as well as an occasional referee for the journal. She is also a past president (2013-14) of RUSA.

Knowing that the journal is in exceedingly competent hands makes turning over the editorship easier. Like my predecessor did for me in 2012, I wish Kathleen the best of luck and know that she will find, as I did, that there is no professional experience as rewarding as editing RUSQ.

\section{Reference}

1. Diane Zabel, "Goodbye and Good Luck," Reference \& User Services Quarterly 51, no. 4 (Summer 2012): 306, https://doi.org/10 $.5860 /$ rusq. $5 \ln 4.306$ 